\title{
A systematic review of physical activity promotion strategies
}

\author{
Melvyn Hillsdon, Margaret Thorogood
}

Regular physical activity can play an important role in both the prevention and treatment of cardiovascular disease, hypertension, noninsulin-dependent diabetes mellitus, stroke, some cancers, osteoporosis and depression, as well as improving the lipid profile. ${ }^{1-8}$ A metaanalysis of the relation between physical activity and coronary heart disease reported that the relative risk of coronary heart disease death in the least active compared with the most active was 1.9-fold. 9 The magnitude of this relative risk is similar to that of the other important cardiovascular disease risk factors, cigarette smoking, hypertension, and hyperlipidaemia. ${ }^{10}$

Despite this evidence, it is estimated that $70 \%$ of the English population takes inadequate physical activity. ${ }^{11}$ compared to $31 \%$ who smoke, $30 \%$ with a raised serum cholesterol concentration, and $15 \%$ who are hypertensive. ${ }^{12}$

In 1995 the Centers for Disease Control and Prevention (USA) and the American College of Sports Medicine recognised the importance of physical activity and published a public health message recommending that "every adult should accumulate 30 minutes or more of moderate-intensity physical activity on most, preferably all days of the week". ${ }^{13}$ In March of this year the Health Education Authority also recognised the public health potential of physical activity, by embarking on a three year national campaign (Active for Life) at promoting the same message.

Although a large body of evidence exists about the health benefits of physical activity, far less is known about the effectiveness of strategies to achieve the increases in physical activity necessary to acquire these benefits.

In this paper we report a revised and updated version of a previous systematic review of randomised controlled trials of physical activity promotion in apparently healthy, free living adults. ${ }^{14}$ The aim of the paper is to provide recent and reliable information on the effectiveness of physical activity promotion.

There are randomised, controlled trials using exercise as an intervention to study the physiological effects of exercise and in the management of health problems, notably hypertension, hyperlipidaemia, and overweight. These show the effects of exercise on various physiological and biological outcomes and demonstrate the importance of exercise in the management of disease. However, because the main outcome of such trials is not physical activity, they do not help us understand the effectiveness of physical activity promotion strategies. For these reasons they were not considered for this review.

\section{Methods}

Computerised searches were carried out using Medline, Excerpta Medica, Sport, and SCISearch from 1966-1996. The method described by Dickersin and colleagues ${ }^{15}$ was used to search for randomised controlled trials on Medline. Key words for searching included "exercise", "physical activity", and "Randomised-Controlled-Trial". The search was limited to English language journals. Additional searching was carried out using the references from both existing reviews $s^{16-18}$ and the papers identified during the search. In addition to the studies described previously, a further 10 studies were found. Those studies included in the previous review were reread by both of us independently, as were the new studies identified during this search. Each paper was read and assessed using a shortened version of the EPI-Centre Review Guidelines. ${ }^{19}$

The criteria for inclusion of trials in the review were:

- a control group

- subjects assigned to control or intervention by a process of randomisation

- trials testing single factor interventions to increase activity

- interventions tested on apparently healthy, free living adults

- minimum of 12 weeks duration

- exercise behaviour was the dependent variable

\section{Results}

Ten new trials were identified, with three meeting the inclusion criteria. Two of the 10 trials in the earlier review were excluded. One of these $\mathrm{e}^{20}$ did not meet the new criterion of 12 weeks minimum duration and we decided on rereading that the other did not describe the exercise level of the control group postintervention. ${ }^{21}$ The 11 trials which are included in this review are described in table $1 A$ and $B$ (studies 5 and 6 are from the same paper and are reported separately for convenience). All the trials were from the USA. We did not find any from the United Kingdom 
that met the inclusion criteria, although we are aware of some that are in progress. Subjects were mainly white, middle aged, and well educated. Most subjects were volunteers, recruited through local advertisements. The trials include an even mix of males and females with an age range of 18-72 years (mean approximately 49).

\section{INTERVENTIONS}

Table 1 summarises the main exercise components of the trials and table 2 the results. Both tables are sorted by location (home or facility) of exercise and then by outcome. Intervention periods ranged from five weeks to two years. Seven of the trials included postintervention follow up periods which ranged from two months to 12 years. Most outcomes were analysed on an intention to treat basis. In the trials, subjects were asked to exercise between three and five times per week for 20-60 minutes. Few studies described the exercise intensity, but when it was described there was a mixture of moderate and vigorous intensities.

\section{Location of exercise}

The location of the prescribed exercise was the home for seven of the trials (table 1). By "home location" we refer to exercise that can take place in proximity to the subjects' homes rather than within their homes. Five of the home based trials (studies 1-5) reported a positive outcome of the intervention. One of the trials (study 6) not showing a significant difference between groups was a comparison between subjects receiving telephone contact and those not receiving it. All of the subjects were sedentary at baseline and significantly increased their exercise level during the intervention. Those subjects receiving telephone support exercised more than those who did not, but the difference did not reach significance. Study 7 , the other home based trial which did not show a significant difference postintervention, did not involve giving specific advice to subjects about increasing their exercise. Subjects in this trial were given either a fitness test, a health appraisal, or both and were given feedback on the results. None of the three intervention groups exercised more than the control group.

Facility based trials normally required the subjects to attend specific sessions or groups at a local fitness centre or indoor track. Only two of the five facility based trials showed a significant difference between intervention subjects and controls.

Study 3 compared home based and facility based exercise. After one year, subjects assigned to the two home based arms completed significantly more of the prescribed exercise sessions than subjects assigned to exercise at a facility $(79 \%, 75 \%$, and $53 \%$ respectively), with no significant difference between the two home based arms.

Components of prescribed exercise

In half of the trials in table 1 , walking was the prescribed mode of exercise. All of the trials showed a significant increase in exercise when compared to controls. In one study (study 1), $80 \%$ of subjects were walking an average of at least five miles per week, with $61 \%$ of subjects adhering to the prescribed level of seven miles per week at two years. Those trials in which walking was not recommended (studies 9-12) included exercise to music classes, gym based "endurance activity", and jogging. Only one of these trials (study 9) showed an increase in exercise. Subjects were females aged 18-20 years, who may have tolerated the prescribed jogging better than the older groups in the other trials.

Although the prescribed frequency of exercise averaged three to five times per week, most subjects were reporting lower frequency at follow up, with an average two to three times per week. Study 3 assigned subjects to three intervention arms of varying frequencies. One of the two home based arms prescribed three sessions per week for 40 minutes at a high intensity, while the other home based arm prescribed five sessions per week at a low intensity. The third arm, where subjects exercised at a local community hall, prescribed three sessions per week. At one year there was no significant difference between the two home based arms on the percentage of prescribed sessions completed, with both completing significantly more than subjects in the facility based arm. Second year ${ }^{33}$ follow up data show that subjects in the three times per week home based arm were able to maintain significantly higher levels of adherence than those in the five times per week home based arm who had reduced to a level similar to that of the facility based arm $(68 \%, 49 \%$, and $36 \%$ of prescribed sessions respectively). Although the two home based arms were prescribed differing intensity levels, analysis of heart rate data showed that both arms actually exercised at an intensity normally described as moderate.

\section{Strategies for improving compliance}

A range of behavioural methods was employed to improve compliance. It is difficult to measure the effect of some of these as they were often part of multifaceted interventions taught to all groups. Methods included reinforcement (rewarding subjects for successful completion), self monitoring (keeping personal records of exercise performed), and relapse prevention training (learning to cope with situations that prompt inactivity and preventing a missed session leading to a return to preintervention exercise levels). Some trials investigated the impact of such strategies with varying results.

In study 4, subjects were randomly assigned to self monitoring, reinforcement, and control arms. After 18 weeks, subjects in the two behavioural treatment arms were exercising significantly more than those in the control arm. Study 11 found no difference in exercise levels between subjects instructed in self monitoring and control subjects. Study 5 took subjects from an earlier trial and randomised them to two "maintenance" groups with different frequencies of self monitoring. Subjects completing daily self monitoring 
Table $1 \mathrm{~A}$ Summary of interventions: home based

\begin{tabular}{|c|c|c|c|c|c|c|}
\hline Study & $\begin{array}{l}\text { Authors, year of publication, stated } \\
\text { objectives }\end{array}$ & $\begin{array}{l}\text { Length of } \\
\text { intervention }\end{array}$ & $\begin{array}{l}\text { Location of } \\
\text { exercise (home } \\
\text { or facility) }\end{array}$ & $\begin{array}{l}\text { Authors' description } \\
\text { of exercise }\end{array}$ & $\begin{array}{l}\text { Prescribed frequency, intensity, and } \\
\text { duration of exercise }\end{array}$ & Controls \\
\hline 1 & $\begin{array}{l}\text { Kriska }{ }^{22} \text { - To examine factors } \\
\text { associated with exercise } \\
\text { compliance in post menopausal } \\
\text { women }\end{array}$ & 2 years & $\begin{array}{l}\text { Home } \\
\text { following } \\
\text { initial } 8 \\
\text { weeks }\end{array}$ & Walking & $3 \times$ wk $/ 3$ miles per session briskly & Assessment only \\
\hline 2 & $\begin{array}{l}\text { Lombard }{ }^{23}-\text { To determine the } \\
\text { effect of frequency and structure of } \\
\text { telephone prompts on frequency of } \\
\text { walking }\end{array}$ & 12 weeks & Home & $\begin{array}{l}\text { Walking (group } \\
\text { walking } \\
\text { encouraged) }\end{array}$ & $3 \times$ wk at least $20 \mathrm{~min}$ per session & Initial instruction \\
\hline 3 & $\begin{array}{l}\mathrm{King}^{24}-\text { To determine the } \\
\text { effectiveness of group } v \text { home } \\
\text { based training of higher and lower } \\
\text { intensities }\end{array}$ & 1 year & $\begin{array}{l}2 \text { groups } \\
\text { home, } 1 \\
\text { group facility }\end{array}$ & $\begin{array}{l}\text { Walking and } \\
\text { jogging }\end{array}$ & $\begin{array}{l}\text { Two groups } 3 \times \text { wk at } 73-88 \% \\
\text { peak heart rate for } 40 \text { min per } \\
\text { session, one group } 5 \times \text { wk at } \\
60-73 \% \text { peak heart rate for } 30 \mathrm{~min} \\
\text { each session }\end{array}$ & Assessment only \\
\hline 4 & $\begin{array}{l}\text { Noland }{ }^{25} \text { - To assess effects of } \\
\text { behavioural techniques on } \\
\text { adherence to unsupervised exercise }\end{array}$ & 18 weeks & Home & $\begin{array}{l}\text { Walking, jogging } \\
\text { and swimming as } \\
\text { preferred }\end{array}$ & $\begin{array}{l}3 \times \text { wk at } 30-40 \% \text { or } 60-70 \% \\
\mathrm{VO}_{2} \max \text { for } 30 \mathrm{~min}\end{array}$ & $\begin{array}{l}\text { Assessment and advice about } \\
\text { exercise; no behavioural } \\
\text { treatment }\end{array}$ \\
\hline 5 & $\begin{array}{l}\text { King }{ }^{26} \text { - To evaluate strategies for } \\
\text { enhancing the maintenance of } \\
\text { exercise training by healthy middle } \\
\text { aged men and women (also see } \\
\text { No } 6 \text { ) }\end{array}$ & 6 months & Home & $\begin{array}{l}\text { Walking and } \\
\text { jogging }\end{array}$ & $\begin{array}{l}4 \times \text { wk at } 65-77 \% \text { peak heart rate } \\
\text { for } 30 \text { min per session }\end{array}$ & $\begin{array}{l}\text { Same as intervention group } \\
\text { but reduced level of self } \\
\text { monitoring }\end{array}$ \\
\hline 6 & $\begin{array}{l}\text { King }^{26} \text { - To evaluate strategies for } \\
\text { enhancing the adoption of exercise } \\
\text { training by healthy middle aged } \\
\text { men and women (also see No } 5 \text { ) }\end{array}$ & 6 months & Home & $\begin{array}{l}\text { Walking and } \\
\text { jogging }\end{array}$ & $\begin{array}{l}4 \times \text { wk at } 65-77 \% \text { peak heart rate } \\
\text { for } 30 \text { min per session }\end{array}$ & $\begin{array}{l}\text { Same as intervention group } \\
\text { less regular telephone contact }\end{array}$ \\
\hline 7 & $\begin{array}{l}\text { Godin }{ }^{27}-\text { To investigate the } \\
\text { effectiveness of fitness testing and } \\
\text { health appraisal on exercise } \\
\text { intention and behaviour }\end{array}$ & 3 months & Home & $\begin{array}{l}\text { Physical activity } \\
\text { lasting } 20-30 \mathrm{~min} \\
\text { per session }\end{array}$ & None prescribed & Assessment only \\
\hline
\end{tabular}

forms performed $35 \%$ more exercise sessions than subjects completing forms weekly.

Relapse prevention training was compared with reinforcement strategies in a study of females attending exercise classes (study 12). Subjects in the relapse prevention arm attended weekly lessons on relapse prevention immediately following an exercise class, while subjects in the reinforcement group received $T$ shirts and other rewards for successful attendance at a number of classes. Control subjects simply attended the exercise classes. At 18 weeks there was no difference between groups on number of exercise sessions attended, with $72 \%$ of subjects attending less than the prescribed three classes per week.

In a trial of jogging alone or in a group, and of jogging with and without relapse prevention training (study 9), the impact of relapse prevention varied. Eighty three per cent $(10 / 12)$ of subjects with relapse prevention training who were jogging alone were still exercising at three months, compared with $36 \%(5 / 12)$ of those without such training. By contrast, in the two group jogging arms relapse prevention training did not increase jogging frequency at follow up.

Study 3 investigated the effect of subjects' perceptions of whether they had achieved expected physical or psychological benefits after six months on subsequent exercise adherence. ${ }^{34}$ Those subjects who reported they had achieved expected benefits completed more exercise sessions in the next six months than those who did not achieve their expectations. It seems that to maintain adherence in the long term, subjects need to perceive a physical or psychological gain from exercise.

Perhaps more important than any of these behavioural methods in achieving high rates of compliance is ongoing follow up.

Table $2 A$ Summary of results: home based

\begin{tabular}{|c|c|c|c|c|c|c|c|}
\hline Study & $\begin{array}{l}\text { Data analysed } \\
\text { by "intention to } \\
\text { treat" }\end{array}$ & $\begin{array}{l}\text { No in } \\
\text { Study }\end{array}$ & Subjects & $\begin{array}{l}\text { Post } \\
\text { intervention } \\
\text { follow up }\end{array}$ & $\begin{array}{l}\text { Actual frequency, intensity, and duration } \\
\text { of exercise intervention group }\end{array}$ & Main outcomes $P<0.05$ & $\begin{array}{l}\text { Outcome } \\
+ \text { or } 0\end{array}$ \\
\hline 1 & Yes & 229 & $\begin{array}{l}\text { Post menopausal } \\
\text { women aged 50-65 }\end{array}$ & Annually & Mean miles walking/wk $=8.4$ & $\begin{array}{l}\text { Self reported walking level } \\
\text { significantly higher at years } 1 \text { and } 2 \\
\text { compared to controls }\end{array}$ & + \\
\hline 2 & Yes & 135 & $\begin{array}{l}\text { University staff and } \\
\text { faculty members, mean } \\
\text { age } 40 \text {, mainly female }\end{array}$ & 12 weeks & $\begin{array}{l}46 \% \text { of frequent prompt groups } \\
\text { walking } 3 \times 20 \text { min per week; } 13 \% \text { of } \\
\text { low frequency prompts; } 4 \% \text { controls }\end{array}$ & $\begin{array}{l}\text { Frequent telephone contact improved } \\
\text { adherence to walking proramme }\end{array}$ & + \\
\hline 3 & Yes & 357 & $\begin{array}{l}160 \text { women and } 197 \\
\text { men aged } 50-65 . \\
\text { Predominantly white } \\
\text { and well educated }\end{array}$ & Ongoing & $\begin{array}{l}\text { Mean frequency }=\mathrm{HIG} \sim 1.2 \times \mathrm{wk} \\
\mathrm{HIH} \sim 2 \times \mathrm{wk}, \mathrm{LIH} \sim 3 \times \mathrm{wk}\end{array}$ & $\begin{array}{l}\text { Significant difference between } \\
\text { intervention and control groups plus } \\
\text { significant difference between home } \\
\text { based and facility based groups }\end{array}$ & + \\
\hline 4 & No & 77 & $\begin{array}{l}28 \text { men (mean age } 40 \text { ) } \\
\text { and } 49 \text { women (mean } \\
\text { age } 36 \text { ) }\end{array}$ & Nil & $\begin{array}{l}\text { Self monitoring group = mean of } \\
2 \cdot 4 / \text { week for } 26 \mathrm{~min} \\
\text { Reinforcement group = mean of } \\
2 \cdot 5 / \text { week for } 29 \text { min }\end{array}$ & $\begin{array}{l}\text { Behavioural interventions increased } \\
\text { frequency of exercise compared to } \\
\text { controls }\end{array}$ & + \\
\hline 5 & Yes & 51 & $\begin{array}{l}\text { Male and female } \\
\text { middle aged subjects }\end{array}$ & Nil & $\begin{array}{l}11.4 \text { sessions/month for daily self } \\
\text { monitoring group; } 7.5 \text { sessions/month } \\
\text { for weekly self monitoring group }\end{array}$ & $\begin{array}{l}\text { Significant difference in number of } \\
\text { exercise sessions/month between } \\
\text { groups }\end{array}$ & + \\
\hline 6 & Yes & 52 & $\begin{array}{l}\text { Male and female } \\
\text { middle aged subjects }\end{array}$ & Nil & $\begin{array}{l}12.4 \text { sessions } / \text { month for } 32 \mathrm{~min} \text { in } \\
\text { telephone group; } 9.8 \text { sessions } / \text { month } \\
\text { for } 28 \mathrm{~min} \text { in comparison group }\end{array}$ & $\begin{array}{l}\text { No significant difference in mean } \\
\text { number of exercise sessions/month } \\
\text { between groups. Both groups } \\
\text { increased exercise frequency over } \\
\text { baseline }\end{array}$ & 0 \\
\hline 7 & No & 200 & Average age $39( \pm 9)$ & None & $\sim 2-3$ sessions/month & No difference between groups & 0 \\
\hline
\end{tabular}

+ , positive significant difference; 0 , no significant difference. 
Table $1 B$ Summary of interventions: facility based

\begin{tabular}{|c|c|c|c|c|c|c|}
\hline Study & $\begin{array}{l}\text { Authors, year of publication, stated } \\
\text { objectives }\end{array}$ & $\begin{array}{l}\text { Length of } \\
\text { intervention }\end{array}$ & $\begin{array}{l}\text { Location of } \\
\text { exercise (home } \\
\text { or facility) }\end{array}$ & $\begin{array}{l}\text { Authors' description } \\
\text { of exercise }\end{array}$ & $\begin{array}{l}\text { Prescribed frequency, intensity, and } \\
\text { duration of exercise }\end{array}$ & Controls \\
\hline 8 & $\begin{array}{l}\text { McAuley }{ }^{28}-\text { To determine the } \\
\text { utility of an efficacy based } \\
\text { intervention on exercise } \\
\text { participation }\end{array}$ & 20 weeks & Facility & Walking & $3 \times \mathrm{wk}, 40 \mathrm{~min}$ & $\begin{array}{l}\text { Initial instruction }+ \text { exercise } \\
\text { information classes }\end{array}$ \\
\hline 9 & $\begin{array}{l}\text { King }{ }^{29}-\text { To study the effect of two } \\
\text { low cost methods of increasing the } \\
\text { number of participant controlled } \\
\text { jogging episodes }\end{array}$ & 5 weeks & Facility & Jogging & $\begin{array}{l}4 \times w k \text {, individualised time and } \\
\text { distance goals }\end{array}$ & Instructed to jog alone \\
\hline 10 & $\begin{array}{l}\text { MacKeen }{ }^{30}-\text { To study the effects } \\
\text { of an } 18 \text { month exercise } \\
\text { intervention on adherence }\end{array}$ & 18 months & $\begin{array}{l}\text { Facility and } \\
\text { Home }\end{array}$ & $\begin{array}{l}\text { Jogging, swimming, } \\
\text { games }\end{array}$ & $\begin{array}{l}3 \times \text { wk minimum, } 35-75 \text { minutes } \\
\text { per session }\end{array}$ & Assessment only \\
\hline 11 & $\begin{array}{l}\text { Reid }{ }^{31} \text { - To assess the effectiveness } \\
\text { of physician prescribed exercise } \\
\text { proramme with health education } \\
\text { and self monitoring components }\end{array}$ & 1 hour & Facility & Endurance activity & $\begin{array}{l}\text { Advice about frequency, intensity, } \\
\text { duration given but not described }\end{array}$ & $\begin{array}{l}\text { Assessment and written } \\
\text { exercise advice }\end{array}$ \\
\hline 12 & $\begin{array}{l}\text { Marcus } 32 \text { - To assess effectiveness } \\
\text { of a relapse prevention programme } \\
\text { and reinforcement programme in } \\
\text { increasing exercise adherence and } \\
\text { short term maintenance }\end{array}$ & 18 weeks & Facility & $\begin{array}{l}\text { Exercise to music } \\
\text { class }\end{array}$ & $35-50$ minutes $3 \times w k$ & $\begin{array}{l}\text { Attendance at exercise group, } \\
\text { no behavioural technique }\end{array}$ \\
\hline
\end{tabular}

Follow up

Telephone calling was a common method for following up clients in home based trials after an initial instruction session. All of the home based trials where researchers maintained contact with clients by telephone reported positive outcomes. Studies 2 and 6 investigated the effect of telephone prompting. Study 2 randomised subjects to four levels of telephone prompting or to a control arm. All subjects received 15 minutes of instruction on walking. At six months there was a significant difference in numbers of subjects still walking between the three prompted arms and the control arm, and between prompt frequency (once per week versus once every three weeks). Study 6 randomly assigned subjects who were waiting list controls from a previous trial ${ }^{35}$ to two interventions, one of which received telephone contact (10 times during six months). All subjects received instructions in behavioural methods to improve compliance. Subjects in the telephone prompting arm exercised more frequently and for longer than those in the control arm (12.4 sessions/month for 32 minutes versus 9.8 sessions/month for 28 minutes). This difference did not achieve significance. Only subjects in the telephone arm significantly increased their fitness.

\section{Discussion}

We have not attempted a formal meta-analysis of the trials in this review since this would be inappropriate in view of the incompatible data and varying quality of the trials described. This is in accordance with the criteria for attempting a meta-analysis described by Eysenck. ${ }^{36}$ The important public health question is whether evidence exists to guide policy makers considering strategies to increase the activity levels of a sedentary population. Trials that were able to demonstrate significant increases in activity involved exercise that was home based, of moderate intensity, involved walking, and had regular follow up.

Walking from home was more successful than exercise which relied on attendance at structured exercise sessions. Only two facility based trials reported increases in exercise, compared with six of the home based trials. All those trials prescribing walking reported increases in activity. Moderate intensity activity was also associated with higher compliance rates. Walking on level ground at a brisk pace would be a moderate intensity activity for most people.

In Britain, walking is the most popular leisure time physical activity. ${ }^{37}$ Approximately half the subjects in a recent national survey ${ }^{11}$ walked continuously for at least a mile at least once in the past week. However, only $26 \%$ of men and $21 \%$ of women walked at a brisk or fast pace, and only $14 \%$ of men and $17 \%$ of women aged 55-74 walked at this pace. The 1993 Health Survey for England ${ }^{12}$ confirmed these findings, reporting that $20 \%$ of women

Table $2 B$ Summary of results: facility based

\begin{tabular}{|c|c|c|c|c|c|c|c|}
\hline Study & $\begin{array}{l}\text { Data analysed } \\
\text { by "intention to } \\
\text { treat" }\end{array}$ & $\begin{array}{l}\text { No in } \\
\text { Study }\end{array}$ & Subjects & $\begin{array}{l}\text { Post } \\
\text { intervention } \\
\text { follow up }\end{array}$ & $\begin{array}{l}\text { Actual frequency, intensity, and duration } \\
\text { of exercise intervention group }\end{array}$ & Main outcomes $P<0.05$ & $\begin{array}{l}\text { Outcome } \\
+ \text { or } 0\end{array}$ \\
\hline 8 & Yes & 125 & \multirow{3}{*}{$\begin{array}{l}\text { Previously sedentary, } \\
45-64 \text { year olds } \\
18-20 \text { year old } \\
\text { previously sedentary } \\
\text { female psychology } \\
\text { students } \\
\text { Males aged } 40-59 \text { with } \\
\text { CHD risk factors }\end{array}$} & None & Not stated & \multirow{2}{*}{$\begin{array}{l}\text { Intervention subjects exercised more } \\
\text { frequently and for longer than controls } \\
83 \% \text { of jogging alone }+ \text { relapse } \\
\text { subjects still exercising at follow up } \\
\text { compared to } 36 \% \text { of control subjects }\end{array}$} & + \\
\hline 9 & Yes & 58 & & 2 months & $\begin{array}{l}\text { Mean frequency JAR and } \\
G=2 \cdot 4 / \text { week; } G R=1 \cdot 4 / \text { week }\end{array}$ & & + \\
\hline 10 & No & 171 & & 12 years & $\begin{array}{l}\text { Mean hours jogging/week at year } \\
13=0.3 \text { hours }\end{array}$ & \multirow{3}{*}{$\begin{array}{l}\text { No difference between exercise and } \\
\text { control conditions at follow up on } \\
\text { jogging hours per week } \\
\text { No significant difference between } \\
\text { groups at follow up } \\
\text { No significant difference in attendance } \\
\text { at } 18 \text { weeks or } 2 \text { month follow up }\end{array}$} & 0 \\
\hline 11 & No & 124 & \multirow{2}{*}{$\begin{array}{l}\text { Male firefighters aged } \\
24-56 \\
\text { Previously sedentary, } \\
\text { female university } \\
\text { employees with a mean } \\
\text { age of } 35 \text { years }\end{array}$} & 6 months & Not stated & & 0 \\
\hline 12 & Yes & 120 & & 2 months & $\begin{array}{l}\text { Percentage of classes attended during } \\
\text { the } 18 \text { weeks } R P=51 \%, R=49 \% \text {, } \\
\text { Controls }=44 \%\end{array}$ & & 0 \\
\hline
\end{tabular}

HIG, high intensity group; HIH, high intensity home; LIH, low intensity home; JAR, jogging alone + relapse prevention; G, group jogging; GR, group jogging + relapse prevention; $R P$, relapse prevention; $R$, reinforcement. 
and $30 \%$ of men were classified as moderate walkers (fast or brisk pace), and $38 \%$ of women and $32 \%$ of men classified as light intensity walkers (slow or average pace). Brisk walking is recommended for improving population activity levels by the American College of Sports Medicine and the Centres for Disease Control and Prevention(USA). ${ }^{13}$ In England, the Health Education Authority's Active for Life campaign emphasises the importance of brisk walking for improving one's health.

A United States survey has shown that people in lower income groups, older people, women, blacks and Hispanic people participated in less exercise. ${ }^{38}$ These differences were not seen in the numbers who were walking, which indicates that walking may be more universally accessible than other types of physical activity. In England, physical activity participation is lower in older people, women, those living in council properties, lower education groups, ${ }^{11}$ and lower socioeconomic groups. ${ }^{39}$

Walking is also associated with a lower injury rate than other forms of physical activity. ${ }^{40}$ Injuries are reported as a barrier to exercise particularly in older age groups. ${ }^{11}$ Reviews of the determinants of physical activity report fewer barriers to walking than other types of physical activity. ${ }^{41}$

Some younger men and most other adults would improve their physical fitness if they took up regular brisk walking. (fig 1). ${ }^{42}$ Increases in cardiovascular fitness have been associated with reductions in cardiovascular and all-cause mortality. ${ }^{43} \mathrm{~A}$ report on the health benefits of walking which reviewed the impact of walking on various cardiovascular disease risk factors concluded that "regular walking has the potential to lower blood pressure, improve the lipid profile, reduce body fat, enhance mental well-being and reduce the risk of coronary heart disease." ${ }^{44}$

This review has shown that when walking is recommended and attendance at a facility is not required, significant increases in activity

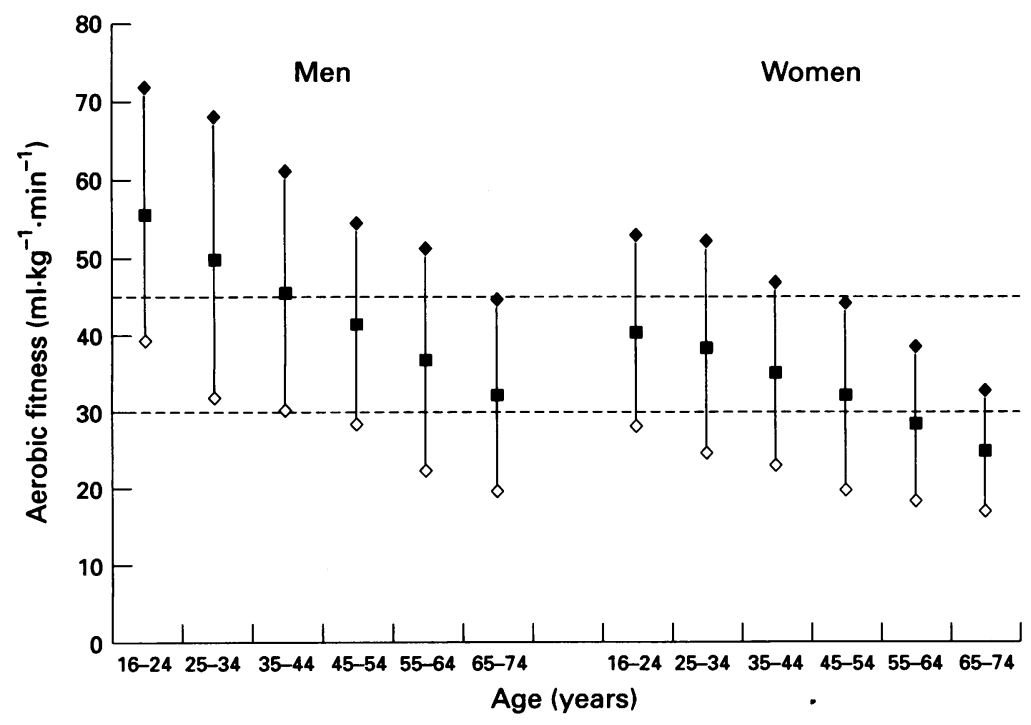

Lines $A$ and $B$ correspond to $45 \mathrm{ml} \cdot \mathrm{kg}^{-1} \cdot \mathrm{min}^{-1}$ and $30 \mathrm{ml} \cdot \mathrm{kg}^{-1} \cdot \mathrm{min}^{-1}$. They define the range of values for aerobic fitness which would permit individuals to perform activities costing between 5 and $7.5 \mathrm{kcal} \cdot \mathrm{min}^{-1}$ (moderate intensity) at about $50 \%$ of their $\mathrm{VO}_{2}$ max. can be achieved. When subjects are followed up regularly the increases can be maintained.

Our findings do not support the current trend in physical activity promotion in this country. There has been a rapid growth in general practitioner (GP) prescription for exercise schemes. Estimates suggest that hundreds of such schemes exist in all parts of the country. A 1994 report $^{45}$ found that a large proportion of such schemes are leisure centre managed, and involve GPs referring patients at reduced or no cost for an average period of 10 weeks. The report estimated that less than $1 \%$ of a GP's patient list was referred into the schemes and also highlighted the fact that "no examples of good evaluation" were found, preventing any conclusions about effectiveness. Although we have been informed of ongoing trials of such schemes, we were unable to find any results published in the scientific literature. The emphasis placed on attending a leisure facility and the neglect of walking as a form of exercise is inconsistent with the findings of this review.

Most of the studies used volunteers responding to advertisements to take part in a physical activity programme. One study (study 3) that used random digit dialling as a method of recruitment only randomised $27 \%$ of those actually contacted, suggesting a high degree of self selection. ${ }^{46}$ These recruitment methods tell us little about how to increase the physical activity levels of the vast majority of people who are unlikely to respond to advertisements.

The findings of this review should be viewed with caution as they are based on only 12 trials all of which were carried out in the USA.

\section{FUTURE RESEARCH}

There is an urgent need for experimental research. In particular:

- there should be trials undertaken in the United Kingdom;

- trials should include groups other than the middle aged, middle class, and white;

- there is a need for trials specifically dealing with physical activity in the over 75s;

- there is a need for evaluation of GP prescription schemes by randomised controlled trials;

- there is a need to evaluate the effect of GPs advising their patients to exercise.

\section{CONCLUSION}

Levels of physical activity can be increased and the increase can be maintained for at least two years. Interventions that encourage walking and do not require attendance at a facility are most likely to lead to sustainable increases in overall physical activity. Regular follow up, which need not be time consuming and expensive, improves the proportion of people able to maintain initial increases.

Brisk walking has the greatest potential for increasing the overall activity levels of a sedentary population and meeting current public health recommendations. It is also the kind of exercise most likely to be adopted by a range of ages, socioeconomic, and ethnic groups as well as both sexes. 
In order to increase the attractiveness of walking for recreational purposes or as a mode of transport, attention will need to be paid to environmental factors which influence personal safety and convenience.

\section{Summary}

We have reviewed randomised controlled trials of physical activity promotion to provide recent and reliable information on the effectiveness of physical activity promotion. Computerised databases and references of references were searched. Experts were contacted and asked for information about existing work. Studies assessed were randomised controlled trials of healthy, free living, adult subjects, where exercise behaviour was the dependent variable. Eleven trials were identified. No United Kingdom based studies were found. Interventions that encourage walking and do not require attendance at a facility are most likely to lead to sustainable increases in overall physical activity. Brisk walking has the greatest potential for increasing overall activity levels of a sedentary population and meeting current public health recommendations. The small number of trials limits the strength of any conclusions and highlights the need for more research.

1 Powell KE, Thompson PD, Caspersen CJ, Kendrick JS Physical activity and the incidence of coronary heart disease. Annu Rev Public Health 1987;8:253-87.

2 American College of Sports Medicine. Physical activity, physical fitness and hypertension. Med Sci Sports Exerc 1993;25:i-x.

3 Helmrich SP, Ragland DR, Leung RW, Paffenbarger RS Physical activity and reduced occurrence of non-insulin dependent diabetes mellitus. $N$ Engl $f$ Med 1991;325:147-52.

4 Shinton R, Sagar G. Lifelong exercise and stroke. $B M \mathcal{F}$ 1993;307:231-4

5 Lee I, Paffenbarger RS, Hsieh C. Physical activity and risk of developing colorectal cancer among college alumni. Natl Cancer Inst 1991;83:1324-9.

6 Drinkwater BL. Physical activity, fitness and osteoporosis In: Bouchard C, Shephard RJ, Stephens T. Physical activity, fitness and health: international proceedings and
consensus statement 1992. Champaign: Human Kinetics consensus statement 1992.

7 North TC, McCullagh P, Vu Tran Z. Effect of exercise on depression. Exerc Sports Sci Rev 1990;18:379-416.

8 Wood PD, Stefanick ML, Williams PT, Haskell WL. The effects on plasma lipoproteins of prudent weight-reducing diet, with or without exercise, in overweight men and women. $N$ Engl f Med 1991;325:461-6.

9 Berlin JA, Colditz GA. A meta-analysis of physical activity in the prevention of coronary heart disease. $A m$ Epidemiol 1990;132:639-46.

10 Pooling Project Research Group. Relationship of blood pressure, serum cholesterol, smoking habit, relative weight and ECG abnormalities to incidence of major coronary events: final report of the pooling project. $\mathcal{f}$ Chronic Dis 1978;31:202-6.

11 Allied Dunbar National Fitness Survey. Main findings. London: Sports Council and Health Education Authority, 1992:46.

12 Office of Population Censuses and Surveys. Health survey for England 1993. London: HMSO, 1995.

13 Pate RR, Pratt M, Blair SN, Haskell WL, Macera CA Bouchard C, et al. Physical activity and public health: recommendation from the Centers for Disease Control and Prevention and the American College of Sports Medicine. $\mathcal{F} A M A$ 1995;273:402-7.

14 Hillsdon M, Thorogood M, Anstiss TA, Morris J. Randomised controlled trials of physical activity promotion in free living populations: a review. $\mathcal{F}$ Epidemiol Community Health 1995;49:448-53.

15 Dickersin $K$, Scherer, Lefebvre C. Identifying relevant studies from systematic reviews. In: Chalmers I, Altman DG, eds. Systematic reviews. London: BMJ Publishing GG, eds. Systematic

16 Dishman RK. Determinants of participation in physical activity. In: Bouchard C, Shephard RJ, Stephens T, Sutton JR, McPherson $\mathrm{BD}$, eds. Exercise, fitness and health: a consensus of current knowledge 1988. Champaign Human Kinetics Publishers, 1990:75-101.
17 King AC, Blair SN, Bild DE, Dishman RK, Dubbert PM, Marcus $\mathrm{BH}$, et al. Determinants of physical activity and interventions in adults. Med Sci Sports Exerc 1992; 24(suppl):S221-36.

18 Dishman RK, Sallis JF. Determinants and interventions for physical activity and exercise. In: Bouchard C, Shephard RJ, Stephens T, eds. Physical activity, fitness and health: international proceedings and consensus statement 1992. international proceedings and consensus statement 1992

19 EPI-Centre. EPI-Centre review guidelines. London: Social Science Research Unit, London University of Education, London, 1996.

20 Hoyt MF, Janis IL. Increasing adherence to a stressful decision via a motivational balance sheet procedure: field experiment. $\mathcal{F}$ Personality Soc Psychol 1975;31:833-9.

21 Suter E, Marti B. Predictors of exercise adoption and adherence of middle-aged sedentary men in a randomised controlled trial. Clin $\mathcal{F}$ Sports Med 1992;2:261-7.

22 Kriska AM, Bayles C, Cauley JA, Laporte RE, Sandler RB, Pambiano G. A randomised exercise trial in older women: increased activity over two years and the factors associated with compliance. Med Sci Sports Exerc 1986;18:557-62.

23 Lombard DN, Lombard TN, Winett RA. Walking to mee health guidelines: the effect of prompting frequency and health guidelines: the effect of prompting frequen
prompt structure. Health Psychol 1995;14:164-70.

24 King AC, Haskell WL, Barr Taylor C, Kraemer HC DeBusk RF. Group vs home based exercise training in healthy older men and women. $f A M A$ 1991;266: $1535-42$.

25 Noland MP. The effects of self monitoring and reinforcement on exercise adherence. Res $Q$ Exerc Spor 1989;60:216-24.

26 King AC, Barr Taylor C, Haskell WL. DeBusk RF Strategies for increasing early adherence to and long term maintenance of home based exercise training in healthy middle aged men and women. Am $\mathcal{f}$ Cardiol 1988; 61:628-32.

27 Godin G, Desharnais, Jobin J, Cook J. The impact of physical fitness and health age appraisal upon exercise intentions and behaviour. $\mathcal{F}$ Behav Med 1987;10:241-50.

28 McAuley E, Courneya KS, Rudolph DL, Lox CL Enhancing exercise adherence in middle-aged males and Enhancing exercise adherence in midd
females. Prev Med 1994;23:498-506.

29 King AC, Frederiksen LW. Low-cost strategies for increasing exercise behaviour. Behav Modif 1984;8:3-21.

30 MacKeen PC, Rosenberger JL, Slater JS, Channing NW, Buskirk ER. A 13 year follow up of a coronary hear disease risk factor screening and exercise programme for 40-59 year old men: exercise habit maintenance and physiologic status. $\mathcal{f}$ Cardiopulm Rehab 1985;5:510-23.

31 Reid EL, Morgan RW. Exercise prescription: a clinical trial Am ₹ Public Health 1979;69:591-5.

32 Marcus BH, Stanton AL. Evaluation of relapse prevention and reinforcement interventions to promote exercise adherence in sedentary females. Res $Q$ Exerc Spon 1993;64:447-52.

33 King AC, Haskell WL, Young DR, Oka RK, Stefanick ML Long term effects of varying intensities and formats of physical activity on participation rates, fitness and lipoproteins in men and women aged $50-65$ years. Circulation 1995;91:2596-604.

34 Neff KL, King AC. Exercise programme adherence in older adults: the importance of achieving one's expected adults: the importance of achieving one's
benefits. Med Exerc Nutr Health 1995;4:355-62.

35 Juneau M, Rogers F, De Santos V, Yee M, Evans A Bohn A, et al. Effectiveness of self monitored, home based moderate intensity exercise training in middle aged men and women. Am $\mathcal{F}$ Cardiol 1987;60:60-70.

36 Eysenck HJ. Problems with meta-analysis. In: Chalmers I Altman DG, eds. Systematic reviews. London: BM Publishing Group, 1995:64-74

37 Office of Population Censuses and Surveys. General household survey 1990. London: HMSO, 1992.

38 Siegel PZ, Brackbill RM, Heath GW. The epidemiology of walking for exercise: implications for promoting activity among sedentary groups. Am f Public Health 1995; 85:706-9

39 Cox BD, Huppert FA, Whichelow MJ. The health and lifestyle survey: seven years on. Aldershot: Dartmouth, 1993.

40 Pollock M, Carroll JF, Graves JE, Leggett SH, Braith RW Limacher $M$, et al. Injuries and adherence to walk/jog and resistance training programs in the elderly. Med Sci Sport Exerc 1991;23:1194-200.

41 Hovell MF, Hofstetter CR, Sallis JF, Rauh MJD, Barrington E. Correlates of change in walking for exercise: an exploratory analysis. Res $Q$ Exerc Spor 1992;63:425-34.

42 Killoran AJ, Fentem, Caspersen C. Moving on: international perspectives on promoting physical activity. London: Health Education Authority, 1994

43 Blair SN, Kohl HW, Barlow CE, Paffenbarger RS, Gibbons LW, Macera CA. Changes in physical fitness and allcause mortality. FAMA 1995;273:1093-8.

44 Davidson RRC, Grant $S$. Is walking sufficient for health? Sports Med 1993;16:369-73.

45 Biddle S, Fox K, Edmunds L. Physical activity promotion in primary health care in England. London: Health Education primary health care

46 King AC, Harris RB, Haskell WL. Effect of recruitment strategy on types of subjects entered into a primary prevention clinical trial. Ann Epidemiol 1994;4:312-20. 